\title{
Comparison of rRNA-based and DNA-based nucleic acid amplifications for detection of Chlamydia trachomatis, Neisseria gonorrhoeae, and Ureaplasma urealyticum in urogenital swabs
}

\author{
Yuying Liang ${ }^{1+}$, Xin $\mathrm{Jin}^{2+}$, Fang Yuan ${ }^{2+}$, Zhanjia $\mathrm{Li}^{2}$ and Shuiping Chen ${ }^{1 *}$
}

\begin{abstract}
Background: Nucleic acid amplification tests (NAAT) are well-accepted in diagnosis and surveillance of sexually infectious pathogens worldwide. However, performance differences between a RNA-based NAAT and DNA-based NAAT are rarely reported. This study compares the performances of the RNA-based SAT (simultaneous amplification and testing) assay and the DNA-based quantitative real-time polymerase chain reaction (qPCR) assay.

Methods: A total of 123 urogenital swabs were collected from outpatients with suspected genital infections in our hospital. Chlamydia trachomatis (CT), Neisseria gonorrhoeae (NG), and Ureaplasma urealyticum (UU) in these swabs were simultaneously tested by SAT and GPCR. Any swabs were positive in the GPCR assay were further verified by following cloning and sequencing. All statistical analysis was performed using the SPSS software.

Results: When the concentrations of CT, NG, or UU were more than $1 \times 10^{3}$ copies $/ \mathrm{ml}, 100 \%$ agreements between SAT and qPCR were observed regardless of the pathogen. No discrepancy was found. However, the sensitivity of SAT is significantly higher than QPCR in samples with concentration less than $1 \times 10^{3}$ copies $/ \mathrm{ml}$. When tested by SAT and qPCR, 57.14 and $28.57 \%$ were positive for $C T, 46.15 \%$ and 0 were positive for NG, $80 \%$ and 0 were positive for UU, respectively.

Conclusions: The SAT assay has better agreements and higher sensitivities when compared with the qPCR assay, and thus could be a better choice for screening, diagnosis, and surveillance of sexually transmitted diseases, especially for CT and NG.
\end{abstract}

Keywords: Chlamydia trachomatis, Neisseria gonorrhoeae, Ureaplasma urealyticum, Simultaneous amplification and testing, $\mathrm{gPCR}$

\section{Background}

Chlamydia trachomatis (CT) and Neisseria gonorrhoeae (NG) are two of the most prevalent sexually infectious pathogenic bacteria worldwide with 131 million chlamydia infections and 78 million gonorrhea infections out of 357 million new infections per year

\footnotetext{
* Correspondence: shpchen@hotmail.com

†Yuying Liang, Xin Jin and Fang Yuan contributed equally to this work. 1 Department of Infection Control, Affiliated Hospital of Academy of Military Medical Sciences, Beijing, People's Republic of China

Full list of author information is available at the end of the article
}

(http://www.who.int/mediacentre/factsheets/fs110/en/). Although Ureaplasma urealyticum (UU) is considered as a commensal bacterium in the urogenital tract, it has been reported to be associated with some sexually transmitted diseases including non-gonococcal urethritis (NGU) $[1,2]$ and patients with high UU loads are associated with acute NGU [2]. Although these infections are curable, screening still remains very important to prevent late complications caused by these pathogens.

(c) The Author(s). 2018 Open Access This article is distributed under the terms of the Creative Commons Attribution 4.0 International License (http://creativecommons.org/licenses/by/4.0/), which permits unrestricted use, distribution, and reproduction in any medium, provided you give appropriate credit to the original author(s) and the source, provide a link to the Creative Commons license, and indicate if changes were made. The Creative Commons Public Domain Dedication waiver (http://creativecommons.org/publicdomain/zero/1.0/) applies to the data made available in this article, unless otherwise stated. 
Traditionally, selective culture methods are used to detect $\mathrm{CT}$, NG, and UU in clinical samples, but their sensitivities are very low [3, 4]. Nucleic acid amplification tests (NAAT), which have a better performance with high sensitivity, specificity, and ease of sample transport, have been approved by the Food and Drug Administration (FDA) for the detection of CT and NG, and widely used in clinical facilities to detect the sexually infectious pathogens $[5,6]$. Recently, a novel RNA-based NAAT (simultaneous amplification and testing, SAT), which is based on transcription mediated amplification (TMA) and designed to detect pathogenic bacteria by amplification of $16 \mathrm{~S}$ rRNA, has been reported to detect some sexual, respiratory, and enteric pathogens, including $\mathrm{CT}$, NG, UU, Mycoplasma genitalium, Mycobacterium tuberculosis, Mycoplasma pneumonniae, entervirus 71, and coxsackievirus A16 [7-11]. SAT provides a great advantage because rRNA is about 10,000 times of the copy number of genomic DNA and 1000 times of that of plasmid DNA [12]. It is noteworthy that probes in SAT are labeled with fluorescences [8-11], while probes in another TMA-based detection method, APTIMA, are labeled with chemiluminescences [13]. Performance comparison of the RNA-based SAT with DNA-based NAAT assay is unclear yet.

Here, we compared the performances of the RNA-based SAT assay with the DNA-based quantitative real-time polymerase chain reaction (qPCR) assay by simultaneous detection of CT, NG, and UU in urogenital swabs.

\section{Methods}

\section{Samples}

A total of 123 urogenital swabs were collected from 123 outpatients with suspected genital infections in our hospital, which consisted of 64 male and 59 female with a median age of 29 years old (range: 19-63). Swabs were placed into $2 \mathrm{ml}$ of sterile normal saline and the tubes were vortexed. For each sample, the two NAATs were performed at the same time. RNase-free tubes and tips were used in the SAT assay.

This study was exempted from a requirement for a statement of ethical approval from ethical committee of the affiliated hospital of academy of military medical sciences.

\section{DNA extraction and the qPCR assay}

CT, NG, and UU qPCR kits (Liferiver Biotech) were used in the DNA-based NAAT. $1 \mathrm{ml}$ of each sample was centrifuged at $13000 \mathrm{~g}$ for $5 \mathrm{~min}$ at room temperature. The supernatant was discarded and the pellet was washed twice with normal saline. After the second wash, the pellet was resuspended in $100 \mu$ l extraction buffer and heated at $100^{\circ} \mathrm{C}$ for $10 \mathrm{~min}$. After another centrifugation at $13000 \mathrm{~g}$ for $5 \mathrm{~min}$, the supernatants were collected and used as DNA extracts.
The reaction mixtures were prepared as described by the manufacturer's instructions. The amplifications were performed on a Roche LightCycler 480 system under the following conditions: $94^{\circ} \mathrm{C} 2 \mathrm{~min}, 40$ cycles of $93^{\circ} \mathrm{C} 15 \mathrm{~s}$ and $60^{\circ} \mathrm{C} 60 \mathrm{~s}$. If the qPCR assay was positive, the amplified segments were subjected to cloning and sequencing to confirm whether they were true or not. Both negative and positive controls were included in each run.

\section{The SAT assay}

Briefly, 16S rRNA was isolated from samples by a capture oligomer via target capture by magnetic microparticles. The target rRNA was then reverse transcribed to generate cDNA fragments using Moloney murine leukemia virus reverse transcriptase and multiple RNA copies (100-1000) were produced from each cDNA copy by the T7 RNA polymerase. Afterwards, these RNA copies were transcribed into cDNA again and bound to fluorescence-labeled specific probes, which were labeled with 6-carboxyfluorescein (FAM) phosphoramidite at the $5^{\prime}$ end and with 4-[4-(dimethylamino) phenylazo] benzoic acid N-succinimidyl ester (DABCYL) at the 3' end [10]. The SAT assay was performed according to the manufacturer's instructions (Shanghai Rendu Biotechnology Co, Ltd). $400 \mu \mathrm{l}$ of samples and $100 \mu \mathrm{l}$ RNA nucleic acid extraction buffer were mixed in a $1.5 \mathrm{ml}$ microcentrifuge tube and heated at $60^{\circ} \mathrm{C}$ for $5 \mathrm{~min}$. After incubation at room temperature for $10 \mathrm{~min}$, RNA extraction was performed by magnetic beads. $30 \mu \mathrm{l}$ of RNA extracts and $40 \mu \mathrm{l}$ of amplification detection buffer were mixed as the final reaction mixture. After incubation at $60^{\circ} \mathrm{C}$ for $10 \mathrm{~min}$, the reaction mixture was immediately placed at $42^{\circ} \mathrm{C}$ for $5 \mathrm{~min} .10 \mu \mathrm{l}$ of pre-heated (42 ${ }^{\circ} \mathrm{C}$ ) enzyme reagent was then added. The tubes were immediately placed on a Roche LightCycler ${ }^{\circ} 480$ system and subjected to amplification with the following conditions: 40 cycles of $42{ }^{\circ} \mathrm{C}$ for $1 \mathrm{~min}$. Both negative and positive controls were included in each run.

To evaluate the reproducibility of SAT, high (original) and low (100-fold diluted) concentrations of the positive controls in the kits (CT: $10^{4}$ and $10^{2}$ copies/ $\mu$ l; NG: $10^{4}$ and $10^{2}$ copies/ $\mu \mathrm{l}$; UU: $2 \times 10^{5}$ and $2 \times 10^{3} \mathrm{cfu} / \mathrm{ml}$ ) were tested, respectively. Each control sample was tested five times.

\section{Statistical analysis}

All statistical analysis was performed using the SPSS software package version 20.0. Frequencies were compared using Fisher's exact test. $p$ values less than 0.05 were considered statistically significant.

\section{Results}

All swabs were firstly detected by the qPCR assay. Of the 123 urogenital swabs, 33 swabs were positive for CT, 32 swabs were positive for NG, and 29 swabs were 
positive for UU after confirmation by the qPCR assay and sequencing. All positive swabs had a concentration of more than $1 \times 10^{3}$ copies $/ \mathrm{ml}$. The remaining 29 swabs were negative for CT, NG, and UU.

\section{Excellent agreements between the SAT assay and the qPCR assay}

After 19 of the 33 CT-positive, 19 of the 32 NG-positive, 19 of the 29 UU-positive, and 29 pathogen-negative samples were tested by SAT, $100 \%$ agreements between the SAT assay and the qPCR assay were observed in samples with a concentration more than $1 \times 10^{3}$ copies $/ \mathrm{ml}$, as shown in Table 1 . Specifically, the sensitivity and specificity were $100 \%(19 / 19)$ and $100 \%(10 / 10)$ for CT, $100 \%$ $(19 / 19)$ and $100 \%$ (10/10) for NG, and 100\% (19/19) and $100 \%(10 / 10)$ for UU, respectively. No discrepancy was found. In addition, SAT exhibited a good reproducibility. Specifically, the coefficient of variations $(\mathrm{CV})$ of CT, NG, and UU were $1.91,2.94$, and $1.25 \%$ for high concentration of positive controls, and 3.14, 0.28 , and $2.28 \%$ for low concentration of positive controls, respectively.

The SAT assay had higher sensitivity than the qPCR assay Because the minimum quantification limits of CT, NG, and UU qPCR kits (Liferiver Biotech) were $1 \times 10^{3}$ copies $/ \mathrm{ml}$, samples with concentrations less than the limit could not be accurately quantified or might be detected as negative. Thus, samples with concentrations less than $1 \times 10^{3}$ copies/ml would be ideal to evaluate the sensitivities. However, due to less availability of this kind of samples, especially NG samples, diluted samples were used here. The remaining 14 of the 33 CT-positive, 13 of the 32 NG-positive, and 10 of the 29 UU-positive were diluted to $1 \times 10^{2}$ copies $/ \mathrm{ml}$. Then, nucleic acids (DNA and RNA) of these diluted samples were simultaneously isolated and tested using both of the SAT assay and the qPCR assay.

Among the 14 CT samples, 28.57\% (4/14) was positive in the qPCR assay, while $57.14 \%(8 / 14)$ was positive in the SAT assay (Table 2). Among the 13 NG samples, none
Table 2 Comparison of $C T, N G$, and $U U$ results in samples with concentration less than $1 \times 10^{3}$ copies $/ \mathrm{ml}$

\begin{tabular}{|c|c|c|c|c|c|}
\hline & $\begin{array}{l}\text { SAT } \\
(+)\end{array}$ & $\begin{array}{l}\text { SAT } \\
(-)\end{array}$ & $\begin{array}{l}\text { Positive rate } \\
\text { of SAT(\%) }\end{array}$ & $\begin{array}{l}\text { Positive rate } \\
\text { of } \mathrm{qPCR}(\%)\end{array}$ & $\begin{array}{l}\text { Accuracy } \\
\text { rate (\%) }\end{array}$ \\
\hline \multicolumn{6}{|l|}{$\overline{C T}$} \\
\hline qPCR (+) & 4 & 0 & 57.14 & 28.57 & 71.43 \\
\hline qPCR (-) & 4 & 6 & & & \\
\hline \multicolumn{6}{|l|}{$N G$} \\
\hline qPCR (+) & 0 & 0 & 46.15 & 0 & 53.85 \\
\hline qPCR (-) & 6 & 7 & & & \\
\hline \multicolumn{6}{|l|}{ UU } \\
\hline qPCR (+) & 0 & 0 & 80 & 0 & 20 \\
\hline qPCR (-) & 8 & 2 & & & \\
\hline
\end{tabular}

was positive in the qPCR assay, while $46.15 \%(6 / 13)$ was positive in the SAT assay (Table 2). Among the $10 \mathrm{UU}$ samples, none was positive in the GPCR assay, while $80 \%$ $(8 / 10)$ was positive in the SAT assay (Table 2). These results indicated that the SAT assay had higher sensitivities than the qPCR assay in the detection of CT, NG, and UU.

\section{Discussion}

Although the emergence and spread of sexually infectious pathogens remains a major global public health concern, severe diseases caused by CT and NG are curable with antibiotics [14]. Routine screening and test of cure (TOC) after treatments are mainstays of disease control. However, sexually transmitted diseases are frequently asymptomatic and the local pathogen concentrations are too low, which might increase the difficulty of diagnosis. The SAT assay is designed to amplify $16 \mathrm{~S}$ rRNA which has a great number of copies in cells [12]. Thus, the advantage of the SAT assay might be helpful when patients are asymptomatic or pathogen concentrations are very low.

In this study, the SAT assay shows excellent agreement and higher sensitivity when compared with the qPCR assay. The SAT assay detects all bacteria strains (CT, NG, or UU) which are positive by the qPCR assay

Table 1 Comparison of CT, NG, and UU results in samples with concentration more than $1 \times 10^{3}$ copies $/ \mathrm{ml}$

\begin{tabular}{|c|c|c|c|c|c|}
\hline & SAT (+) & SAT $(-)$ & Sensitivity (\%) & Specificity (\%) & Accuracy rate (\%) \\
\hline \multicolumn{6}{|l|}{$\mathrm{CT}$} \\
\hline qPCR (+) & 19 & 0 & 100 & 100 & 100 \\
\hline $\mathrm{qPCR}(-)$ & 0 & 10 & & & \\
\hline \multicolumn{6}{|l|}{ NG } \\
\hline $\mathrm{qPCR}(+)$ & 19 & 0 & 100 & 100 & 100 \\
\hline qPCR (-) & 0 & 10 & & & \\
\hline \multicolumn{6}{|l|}{ UU } \\
\hline $\mathrm{qPCR}(+)$ & 19 & 0 & 100 & 100 & 100 \\
\hline $\mathrm{qPCR}(-)$ & 0 & 9 & & & \\
\hline
\end{tabular}


and there are no discrepant results when direct detection of clinical samples is performed. In addition, the assay can detect pathogens with low concentrations (less than $1 \times 10^{3}$ copies $/ \mathrm{ml}$ ) indicating a higher sensitivity. Our results are consistent with other studies where another rRNA-based assay (APTIMA, Hologic Inc) was compared with DNA-based assays [15-17].

TOC is recommended after initiation of treatment. Because traces of bacterial DNA can persist for prolonged periods after successful elimination of pathogens $[18,19]$ and only live metabolically active bacteria produce RNA, rRNA-based NAAT could potentially discriminate metabolically-active pathogens from dead ones so that RNA might be a better biomarker than DNA during surveillance of treatments. A previous study indicates that $95 \%$ of patients clear bacterial RNA at day 13 which is one day earlier than DNA [20]. These results suggest that rRNA-based NAAT could avoid potential overtreatment. Combination of its sensitivity and specificity, the SAT assay might be an ideal TOC tool during treatment.

Our results show the same results that rRNA-based NAATs appear to offer significantly higher sensitivity than DNA-based NAATs $[15,21]$. Thus, current detections using DNA-based NAATs might underestimate the prevalence of sexually infectious pathogens and overestimated the effectiveness of anti-bacterial treatments.

Our study has three limitations. Firstly, it is performed at a single hospital which might limit the generalizability. Secondly, pathogen-positive samples with concentration less than $1 \times 10^{3}$ copies $/ \mathrm{ml}$ used in this study are diluted from clinical samples due to less availability, which might bias the results. Thirdly, the sample size is small and further large size samples are needed to better understand the performance of the SAT assay. Nevertheless, excellent agreement and higher sensitivity of the SAT assay are warranted in this study.

\section{Conclusions}

This study demonstrates that the SAT assay has excellent agreements and higher sensitivities for CT, NG, and UU detection in urogenital swabs when compared with the qPCR assay. Thus, the SAT assay could be a better choice for screening, diagnosis, and surveillance of sexually transmitted diseases. However, considering high prevalence in healthy populations, UU screening is only recommended in symptomatic patients with suspected urogenital tract infections.

\section{Abbreviations}

$\mathrm{CT}$ : Chlamydia trachomatis; NAAT: Nucleic acid amplification test; NG: Neisseria gonorrhoeae; qPCR: Quantitative real-time polymerase chain reaction; SAT: Simultaneous amplification and testing; UU: Ureaplasma urealyticum
Acknowledgements

Not applicable.

Funding

None.

\section{Availability of data and materials}

The datasets generated/analyzed during this study are not publicly available, but are available from the corresponding author on reasonable request.

\section{Authors' contributions}

SC and YL designed the study. SC drafted and revised the manuscript. YL, XJ, and FY performed the experiments and analyzed the data. ZL extracted

DNA/RNA from samples. All authors read and approved the final manuscript.

Ethics approval and consent to participate

Both ethical approval and consent to participate were waived by the ethical committee of the affiliated hospital of academy of military medical sciences.

Consent for publication

Not applicable.

\section{Competing interests}

The authors declare that they have no competing interests.

\section{Publisher's Note}

Springer Nature remains neutral with regard to jurisdictional claims in published maps and institutional affiliations.

\section{Author details}

${ }^{1}$ Department of Infection Control, Affiliated Hospital of Academy of Military Medical Sciences, Beijing, People's Republic of China. ${ }^{2}$ Department of Laboratory Medicine, Affiliated Hospital of Academy of Military Medical Sciences, Beijing, People's Republic of China.

Received: 16 October 2017 Accepted: 3 December 2018

Published online: 12 December 2018

\section{References}

1. Frølund M, Lidbrink P, Wikström A, Cowan S, Ahrens P, Jensen JS. Urethritisassociated pathogens in urine from men with non-gonococcal urethritis: a case-control study. Acta Derm Venereol. 2016;96:689-94.

2. Zhang N, Wang R, Li X, Liu X, Tang Z, Liu Y. Are Ureaplasma spp. a cause of nongonococcal urethritis? A systematic review and meta-analysis. PLoS One. 2014;9:e113771

3. Serra-Pladevall J, Caballero E, Roig G, Juvé R, Barbera MJ, Andreu A. Comparison between conventional culture and NAATs for the microbiological diagnosis in gonococcal infection. Diagn Microbiol Infect Dis. 2015:83:341-3.

4. Shipitsyna E, Guschin A, Maximova A, Tseslyuk M, Savicheva A, Sokolovsky E, Shipulin G, Domeika M, Unemo M. Comparison of microscopy, culture and in-house PCR and NASBA assays for diagnosis of Neisseria gonorrhoeae in Russia. APMIS. 2008;116:133-8.

5. Tabrizi SN, Unemo M, Limnios AE, Hogan TR, Hjelmevoll SO, Garland SM, Tapsall J. Evaluation of six commercial nucleic acid amplification tests for detection of Neisseria gonorrhoeae and other Neisseria species. J Clin Microbiol. 2011:49:3610-5.

6. Ursi $D$, Crucitti $T$, Smet $H$, leven M. Evaluation of the bio-rad $d x C T / N G / M^{\otimes}$ assay for simultaneous detection of chlamydia trachomatis, Neisseria gonorrhoeae and mycoplasma genitalium in urine. Eur J Clin Microbiol Infect Dis. 2016;35:1159-63.

7. Qing L, Song QX, Feng JL, Li HY, Liu G, Jiang HH. Prevalence of chlamydia trachomatis, Neisseria gonorrhoeae, mycoplasma genitalium and Ureaplasma urealyticum infections using a novel isothermal simultaneous RNA amplification testing method in infertile males. Ann Clin Microbiol Antimicrob. 2017;16:45.

8. Li W, Fang YH, Shen HQ, Yang DH, Shu Q, Shang SQ. Evaluation of a realtime method of simultaneous amplification and testing in diagnosis of mycoplasma pneumoniae infection in children with pneumonia. PLoS One. 2017;12:e0177842 
9. Chen $\mathrm{Q}, \mathrm{Hu}$ Z, Zhang $\mathrm{Q}, \mathrm{Yu}$ M. Development and evaluation of a real-time method for testing human enteroviruses and coxsackievirus A16. Diagn Microbiol Infect Dis. 2016;85:36-41.

10. Xu J, Cao L, Su L, Dong N, Yu M, Ju J. A new accurate assay for Coxsackievirus a 16 by fluorescence detection of isothermal RNA amplification. J Virol Methods. 2013;193:459-62.

11. Cui Z, Wang Y, Fang L, Zheng R, Huang X, Liu X, Zhang G, Rui D, Ju J, Hu Z. Novel real-time simultaneous amplification and testing method to accurately and rapidly detect Mycobacterium tuberculosis complex. J Clin Microbiol. 2012;50:646-50.

12. Mouton JW, Verkooyen R, van der Meijden WI, van Rijsoort-Vos TH, Goessens WH, Kluytmans JA, Deelen SD, Luijendijk A, Verbrugh HA. Detection of chlamydia trachomatis in male and female urine specimens by using the amplified chlamydia trachomatis test. J Clin Microbiol. 1997;35: 1369-72.

13. Chapin K, Andrea S. APTIMA ${ }^{\oplus}$ Trichomonas vaginalis, a transcriptionmediated amplification assay for detection of Trichomonas vaginalis in urogenital specimens. Expert Rev Mol Diagn. 2011;11:679-88.

14. Workowski KA, Bolan GA. Sexually transmitted diseases treatment guidelines, 2015. MMWR Recomm Rep. 2015;64(RR-03):1-137.

15. de Barbeyrac B, Géniaux M, Hocké C, Dupon M, Bébéar C. Detection of chlamydia trachomatis in symptomatic and asymptomatic populations with urogenital specimens by AMP CT (gen-probe incorporated) compared to others commercially available amplification assays. Diagn Microbiol Infect Dis. 2000;37:181-5.

16. Ferrero DV, Meyers HN, Schultz DE, Willis SA. Performance of the gen-probe AMPLIFIED chlamydia trachomatis assay in detecting chlamydia trachomatis in endocervical and urine specimens from women and urethral and urine specimens from men attending sexually transmitted disease and family planning clinics. J Clin Microbiol. 1998;36:3230-3.

17. Yang JL, Schachter J, Moncada J, Habte D, Zerihun M, House J, Zhou Z, Hong KC, Maxey K, Gaynor BD, Lietman TM. Comparison of an rRNA-based and DNA-based nucleic acid amplification test for the detection of chlamydia trachomatis in trachoma. Br J Ophthalmol. 2007;91:293-5.

18. Workowski KA, Lampe MF, Wong KG, Watts MB, Stamm WE. Long-term eradication of chlamydia trachomatis genital infection after antimicrobial therapy. Evidence against persistent infection. JAMA. 1993;270:2071-5.

19. Cangelosi GA, Meschke JS. Dead or alive: molecular assessment of microbial viability. Appl Environ Microbiol. 2014;80:5884-91.

20. Wind CM, Schim van der Loeff MF, Unemo M, Schuurman R, van Dam AP, de Vries HJ. Time to clearance of chlamydia trachomatis RNA and DNA after treatment in patients coinfected with Neisseria gonorrhoeae - a prospective cohort study. BMC Infect Dis. 2016;16:554.

21. Chernesky M, Jang D, Luinstra K, Chong S, Smieja M, Cai W, Hayhoe B, Portillo E, Macritchie C, Main C, Ewert R. High analytical sensitivity and low rates of inhibition may contribute to detection of chlamydia trachomatis in significantly more women by the APTIMA combo 2 assay. J Clin Microbiol. 2006;44:400-5.

Ready to submit your research? Choose BMC and benefit from:

- fast, convenient online submission

- thorough peer review by experienced researchers in your field

- rapid publication on acceptance

- support for research data, including large and complex data types

- gold Open Access which fosters wider collaboration and increased citations

- maximum visibility for your research: over $100 \mathrm{M}$ website views per year

At BMC, research is always in progress.

Learn more biomedcentral.com/submissions 